\title{
Tyrosinase activity of Greyia flanaganii (Bolus) constituents
}

\author{
M.B. Mapunya ${ }^{a}$, A.A. Hussein ${ }^{a, b}$, B. Rodriguez ${ }^{c}$, N. Lall ${ }^{a, *}$ \\ a Department of Plant Science, University of Pretoria, Pretoria 0002, South Africa \\ b Department of Chemistry of Medicinal Plants, National Research Center, El-Tahrir St., Dokki, Cairo, Egypt \\ ${ }^{\mathrm{c}}$ Instituto de Quimica Organica, Consejo Superior de Investigaciones Cientificas (CSIC), Juan de la Cierva 3, E-28006 Madrid, Spain
}

\section{A R T I C L E I N F O}

\section{Keywords:}

Greyia flanaganii

Greyiaceae

Phenolic compounds

Tyrosinase inhibition

Antioxidant

Toxicity

Antibacterial

\begin{abstract}
A B S T R A C T
Hyper-pigmentation of the skin is a common problem that is prevalent in middle aged and elderly people. It is caused by over production of melanin. Tyrosinase is known to be the key enzyme in melanin production. Ethanolic extract of Greyia flanaganii leaves showed significant $(P<0.05)$ antityrosinase activity exhibiting the $\mathrm{IC}_{50}$ of $32.62 \mu \mathrm{g} / \mathrm{ml}$. The total extract was further investigated for its toxicity and effect on melanin production by melanocytes cells, and showed significant inhibition $(P<0.05)(20 \%)$ of melanin production at $6.25 \mu \mathrm{g} / \mathrm{ml}$ and low levels of cytotoxicity $\left(\mathrm{IC}_{50}<400 \mu \mathrm{g} / \mathrm{ml}\right)$. The amount of antioxidants necessary to decrease the initial $\mathrm{DPPH}$ absorbance by $50 \%\left(\mathrm{EC}_{50}\right)$ by the total ethanolic extract was found to be $22.01 \mu \mathrm{g} / \mathrm{ml}$. The effect of $G$. flanaganii against acne causing bacteria, Propionibacterium acnes, was investigated using microdilution assay. The MIC of the extract of $G$. flanaganii was found to be $250 \mu \mathrm{g} / \mathrm{ml}$. Bioassay-guided fractionation led to the isolation of (3S)-4-hydroxyphenethyl 3-hydroxy-5-phenylpentanoate (1), 2',4',6'-trihydroxydihydrochalcone (2), $2^{\prime}, 6^{\prime}, 4$-trihydroxy-4'-methoxydihydrochalcone (3), 2',6'-dihydroxy-4'-methoxydihydrochalcone (4), 5,7dihydroxyflavanone [(2S)-pinocembrin] (5), 2',6'-dihydroxy-4',4-dimethoxy dihydrochalcone (6) and $(2 R, 3 R)-3,5,7$-trihydroxy-3-O-acetylflavanone (7). The isolated compounds were tested for their antioxidant, cytotoxicity, tyrosinase inhibition and antibacterial activities. Compound 2 exhibited significant $(P<0.05)$ antityrosinase activity exhibiting the $\mathrm{IC}_{50}$ of $69.15 \mu \mathrm{M}$. The isolated compounds showed low toxicity of the cells with reduction of melanin content of the cells. All compounds tested showed good radical scavenging activity. These data indicates that $G$. flanaganii extract and its isolated phenolic constituents could be possible skin lightening agents.
\end{abstract}

(c) 2011 Elsevier GmbH. All rights reserved.

\section{Introduction}

Melanin is the pigment responsible for the colour of skin in humans. Tyrosinase is known to be the key enzyme in melanin biosynthesis (Nerya et al. 2003). Over-activity of this enzyme leads to overproduction of melanin leading to hyper-pigmentation of the skin. Hyper-pigmentation can also be caused by excessive exposure to UV light, drug reaction and also occurs during ageing. Overproduction of melanin can be prevented by avoiding excessive UV light exposure and can be treated with skin-lightening agents such as bleaching hydroquinone, kojic acid and retinoids (Halder et al. 2004). Some commercially available chemical and fungal derived skin-lightening agents have been proven to have chronic, cytotoxic and mutagenic effects on humans (Nerya et al. 2003; Wang et al. 2006; Wu et al. 2003). Therefore, there is a need for alternative herbal derived and pharmaceutical agents for the treatment

\footnotetext{
* Corresponding author. Tel.: +27 4202524; fax: +27 3625099.

E-mail address: namrita.lall@up.ac.za (N. Lall).
}

of hyper-pigmentation of the human skin. Plants have formed the sophisticated traditional medicine systems that have been in existence for thousands of years (Anon 1998; Yesilada 2005). The aim of this study was to test the activity of Greyia flanaganii (Bolus) on tyrosinase enzyme. G. flanaganii is an evergreen shrub endemic to Eastern Cape. This plant is very frost tolerant. It is traditionally believed to have the ability to ward off sickness (Mbambezeli 2005). During a study done by Bohm and Chan (1992) it was shown to contain a mixture of flavonoid compounds (an example of known tyrosinase inhibitors).

\section{Materials and methods}

\section{Plant extraction}

Leaves of G. flanaganii were collected during December 2006 from the botanical garden of the University of Pretoria and identified at H.G.W.J Schwelckerdt Herbarium. The samples were air dried, shielded from the sun, at ambient temperatures. The air dried plant material was ground to a fine powder, which was 
<smiles>O=C(CC(O)CCc1ccccc1)OCCc1ccc(O)cc1</smiles>

(3S)-4-hydroxyphenethyl 3-hydroxy-5phenylpentanoate (1)<smiles>COc1cc(O)c(C(=O)CCc2ccc(O)cc2)c(O)c1</smiles>

2',6',4-trihydroxy-4'-methoxydihydrochalcone (3)<smiles>O=C1C[C@H](c2ccccc2)Oc2cc(O)cc(O)c21</smiles>

5,7-dihydroxyflavanone [(2S)-pinocembrin] (5)<smiles>CC(=O)OC1C(=O)c2c(O)cc(O)cc2O[C@H]1c1ccccc1</smiles>

$(2 R, 3 R)-3, .5,7$-trihydroxy-3-O-acetylflavanone (7)<smiles>O=C(CCc1ccccc1)c1c(O)cc(O)cc1O</smiles>

2', 4',6'-trihydroxydihydrochalcone (2)<smiles>COc1ccc(CCC(=O)c2c(O)cc(OC)cc2O)cc1</smiles>

2',6'-dihydroxy-4',4-dimethoxydihydrochalcone

(6)

Fig. 1. Chemical structures of the isolated compounds.

extracted with ethanol. The mixture was left overnight on a shaker at room temperature and then filtered and evaporated under reduced pressure.

\section{Isolation of active compounds}

About $71 \mathrm{~g}$ of the ethanolic extract of $G$. flanaganii was applied to a silica gel column $(70 \mathrm{~cm} \times 120 \mathrm{~cm})$ using hexane fraction (bp $\left.60-80^{\circ} \mathrm{C}\right)(\mathrm{Hex})$ : ethyl acetate (EtOAc) mixtures of increasing polarity (100:0 to 0:100) followed by $100 \%$ methanol (MeOH) as eluents. In total 64 fractions $(500 \mathrm{ml})$ were collected. Similar fractions were combined, according to thin-layer (TLC) profile, which resulted into eight fractions. All the eight fractions were tested for antityrosinase activity using tyrosine as the substrate. Fractions 1, 4 and 6 showed stronger inhibitory activity of the enzyme; hence these fractions were further chromatographed on a sephadex column (LH-20, Sigma Aldrich, South Africa) for the isolation and identification of bioactive compounds using ethanol as an eluent. Fraction 6 yielded pure compounds 1 (114 mg), 2 (253 mg) and 3 (208 mg), while fraction 1 yielded pure compounds $4(20 \mathrm{mg})$ and $\mathbf{5}(20 \mathrm{mg})$, and fraction 4 gave compounds 6 (10 mg) and 7 (10 mg) (Fig. 1).

\section{Colorimetric tyrosinase inhibition assay}

The colorimetric tyrosinase assay was performed using methods described by Curto et al. (1999) and Momtaz et al. (2008). The source of tyrosinase enzyme used in the experiments was Agaricus bisporu, an edible mushroom species which is native to grasslands in Europe and North America. The plant extract and purified compounds were dissolved in dimethyl sulfoxide (DMSO) to a final concentration of $20 \mathrm{mg} / \mathrm{ml}$ (stock solution). This stock solution was then diluted to $600 \mu \mathrm{g} / \mathrm{ml}$ in $50 \mathrm{mM}$ potassium phosphate buffer ( $\mathrm{pH}$ 6.5). Kojic acid was used as a control drug (Lee et al. 1997). In a 96 well microtitre plate, $70 \mu$ l of each sample solution of different concentrations were combined with $30 \mu \mathrm{l}$ of tyrosinase (333 Units/ml in phosphate buffer, pH6.5) in triplicates. After incubation at room temperature for $5 \mathrm{~min}, 110 \mu \mathrm{l}$ of substrate ( $2 \mathrm{mM}$ L-tyrosine or $12 \mathrm{mM} \mathrm{L-DOPA}$ ) were added to each well. Final concentrations of the extract was 200 and $20 \mu \mathrm{g} / \mathrm{ml}$. Final concentrations of the pure compounds and positive controls ranged from 1.56 to $200 \mu \mathrm{g} / \mathrm{ml}$. Microtitre plates were incubated for $30 \mathrm{~min}$ at room temperature. Optical densities of the wells were then determined at $492 \mathrm{~nm}$ with the BIO-TEK 
power Wave XS multi-well plate reader (A.D.P., Weltevreden Park, South Africa). The fifty percent inhibition concentration $\left(\mathrm{IC}_{50}\right)$ value was determined by the use of MSTATC software (East Lansing, MI, VS).

Determination of extract toxicity and melanin content in melanocytes

Mouse melanocytes cell line, B16-F10, was cultured in complete Minimal Essential Eagle's Medium (MEM) containing 10\% Foetal Bovine Serum, $1.5 \mathrm{~g} / \mathrm{l} \mathrm{NaHCO}_{3}, 2 \mathrm{mM}$ L-glutamine, $10 \mu \mathrm{g} / \mathrm{ml}$ penicillin, $10 \mu \mathrm{g} / \mathrm{ml}$ streptomycin, and $0.25 \mu \mathrm{g} / \mathrm{ml}$ fungizone at $37^{\circ} \mathrm{C}$ with $5 \% \mathrm{CO}_{2}$ in a humidified atmosphere. Cells were sub-cultured in a ratio of 1:3 on every third or fourth day. Mouse melanocytes (B16F10) cells in complete MEM medium were dispensed into the wells of a 96 -well plate $\left(10^{4}\right.$ cells per well $)$ and 24 -well plate $\left(10^{5}\right.$ cells per well). After an overnight incubation at $37^{\circ} \mathrm{C}$ in $5 \% \mathrm{CO}_{2}$ and a humidified atmosphere, extract sample and positive controls were added to the cells to the final concentrations of $400,200,100,50,25,12.5$, 6.25 and $3.13 \mu \mathrm{l} / \mathrm{ml}$. Pure compounds were tested in concentrations ranging from 1.5 to $100 \mu \mathrm{g} / \mathrm{ml}$. Plates were incubated at $37^{\circ} \mathrm{C}$ in $5 \% \mathrm{CO}_{2}$, humidified atmosphere for three days. Toxicity effect of the extracts on B16-F10 cells was assayed using XTT (sodium 3'-[1-(phenyl amino-carbonyl)-3,4-tetrazolium]-bis-[4-methoxy6-nitrobenzene sulfonic acid hydrate) cytotoxicity assay. Fifty microlitres of XTT reagent $(1 \mathrm{mg} / \mathrm{ml}$ XTT with $0.383 \mathrm{mg} / \mathrm{ml}$ PMS $)$ was added to the wells and incubated for $1 \mathrm{~h}$. The optical densities of the wells were measured at $450 \mathrm{~nm}$ (690 nm reference wavelength). By comparing to the control (medium with DMSO), cell survival was assessed. The effect of the plant extracts/pure compounds on melanin synthesis was determined by washing the melanocytes cells in the 24-well plate with potassium phosphate buffered saline (PBS), and lysing with $200 \mu$ l of sterile distilled water $\left(\mathrm{dH}_{2} \mathrm{O}\right)$. Optical densities were determined at a wavelength of $405 \mathrm{~nm}$. The effect on melanin production was determined by comparing to the control sample (medium with DMSO). The absorbance of a series of known concentrations of pure melanin was used to construct a calibration curve to determine the amount of melanin produced by the cells.

\section{Antioxidant activities of G. flanaganii extract and purified compounds}

Antioxidant activity of the ethanol extract of Greyia flanaganii (Bolus) and purified compounds was investigated using the 1,2diphenyl-2-picrylhydrazyl (DPPH) (Sigma-Aldrich, South Africa) antioxidant assay. Following the procedures as described by Toit et al. (2001) for each sample, a dilution series (8 dilutions) was prepared in a 96-well ELISA plate by adding distilled water as a dilution medium. Final concentrations of the samples ranged from 0.78 to $100 \mu \mathrm{g} / \mathrm{ml}$. Each concentration was tested in triplcates. Vitamin $C$ was used as the positive control. The radical scavenging capacities of the samples were determined using a BIOTEK plate reader to measure the disappearance of DPPH at $550 \mathrm{~nm}$. The radical scavenging activity was measured in terms of the amount of antioxidants necessary to decrease the initial DPPH absorbance by $50 \%\left(\mathrm{EC}_{50}\right)$ (Toit et al. 2001). The $\mathrm{EC}_{50}$ value for each sample was determined graphically by plotting the absorbance of DPPH as a function of the sample concentration in $\mu \mathrm{g} / \mathrm{ml}$. The $\mathrm{EC}_{50}$ is the amount of antioxidant necessary to decrease the initial DPPH absorbance by $50 \%$. The results are expressed as the mg Vit C equivalents/g dry weight and are calculated as follows: VitEAC $(\mathrm{mg} \mathrm{AA} / 100 \mathrm{~g})=\left(\mathrm{IC}_{50(\text { vit c })} / \mathrm{IC}_{50 \text { (sample })}\right) \times 1000$.

\section{Antibacterial activity}

The minimal inhibitory concentration (MIC) of the ethanolic leaf extract of $G$. flanaganii and isolated compounds was determined by microdilution assay. This assay was done using methods as described by McGaw and Eloff (2005) and Sahin et al. (2003) with slight modifications. The antibacterial activity was investigated against Propionibacterium acnes (ATCC 11827). The bacteria was cultured from a Kwik-Stick on nutrient agar and incubated at $37^{\circ} \mathrm{C}$ for $72 \mathrm{~h}$ under anaerobic conditions before the assay. The $72 \mathrm{~h}$ culture of the bacteria was dissolved in Ringer's solution and the suspensions were adjusted to 0.5 McFarland standard turbidity. This resulted in $10^{7}$ to $10^{8} \mathrm{CFU} / \mathrm{ml}$. Erythromycin was used as the positive control (Lim et al. 2007). The plates were incubated at $37^{\circ} \mathrm{C}$ for $72 \mathrm{~h}$ in an anaerobic condition. The minimum inhibitory concentration (MIC) value was determined by observing the colour change in the wells after addition of p-iodonitrotetrazolium violet salt (INT) (defined as the lowest concentration that showed no bacterial growth).

\section{Statistical analysis}

The results were analyzed statistically using one-way analysis of variance (ANOVA) and the least significant differences $(P<0.05)$ were determined according to Duncan's t-test. Results were significant where $P<0.05$.

\section{Results and discussion}

\section{General procedures}

Melting points were determined on a Kofler block and are uncorrected. Optical rotations: in acetone (6) or $\mathrm{MeOH}(7)$ solution (Perkin-Elmer $241 \mathrm{MC}$ polarimeter). IR: in $\mathrm{KBr}$ (Perkin-Elmer Spectrum One spectrophotometer). ${ }^{1} \mathrm{H}$ and ${ }^{13} \mathrm{C}$ NMR spectra were recorded at room temperature on a Varian SYSTEM $500 \mathrm{MHz}$ spectrometer operating at $500 \mathrm{MHz}$ and $125 \mathrm{MHz}$, respectively. ${ }^{1} \mathrm{H}$ and ${ }^{13} \mathrm{C}$ NMR chemical shifts are reported with respect to the solvent ( $m e t h a n o l-d_{4}$ ) signals ( $\delta 3.30$ for proton and $\delta 49.00$ for carbon). All the ${ }^{1} \mathrm{H}$ and ${ }^{13} \mathrm{C}$ NMR assignments were in agreement with COSY, HSQC and HMBC spectra. Mass spectra: positive EI mode, $70 \mathrm{eV}$, $\mathrm{CH}_{2} \mathrm{Cl}_{2}$ (Hewlett-Packard 5973 spectrometer). HRESIMS: Agilent 6520 Accurate-Mass QTOF LC/MS apparatus.

\section{Structure elucidation of compound 1}

High-resolution mass spectrometry and combustion analysis indicated a molecular formula of $\mathrm{C}_{19} \mathrm{H}_{22} \mathrm{O}_{4}$ for $\mathbf{1}$, and its IR spectrum showed hydroxyl $\left(3446,3312 \mathrm{~cm}^{-1}\right)$ and ester $(1721$, $1183 \mathrm{~cm}^{-1}$ ) absorptions. The ${ }^{1} \mathrm{H}$ and ${ }^{13} \mathrm{C}$ NMR spectra of 1 , together with 2D-NMR COSY and HSQC experiments, revealed that it possessed a 3-hydroxy-5-phenylpentanoic acid ester structural moiety, because the chemical shifts of the $\mathrm{C}-1$ to $\mathrm{C}-11$ protons and carbons (see below and Fig. 1) were almost identical to those reported for the methyl ester of 3-hydroxy-5-phenylvaleric acid (Calis et al. 1999). Moreover, the remaining proton and carbon signals of 1 (C-1' to C-8', see below and Fig. 1) were in complete agreement with those of esterified tyrosol (Bianco et al. 2006). The observed HMBC correlations between the carbonyl carbon of the acyloxy part $(\mathrm{C}-1, \delta 173.4)$ and the $\mathrm{C}-1^{\prime}$ methylene protons of tyrosol ( $\delta 4.22$ and 4.19$)$ further supported that this new substance is 4-hydroxyphenethyl 3-hydroxy-5-phenylpentanoate (1).

The absolute stereochemistry of the C-3 asymmetric center of $\mathbf{1}$ was not ascertained. However, we assume that it possesses a $3 \mathrm{~S}$ absolute configuration because the specific optical rotation of $\mathbf{1}$ 
Table 1

Antityrosinase, toxicity, antioxidant and antibacterial activity of isolated compounds from the leaf extract of Greyia flanaganii.

\begin{tabular}{|c|c|c|c|c|c|c|c|c|c|c|}
\hline \multirow[t]{2}{*}{ Test, $\mu \mathrm{g} / \mathrm{ml} /(\mu \mathrm{M})$} & \multicolumn{7}{|l|}{ Compounds } & \multicolumn{3}{|c|}{ Positive controls } \\
\hline & C1 & C2 & C3 & C4 & C5 & C6 & C7 & Kojic acid & Vit C & Erythromycin \\
\hline Tyrosinase & $>200$ & $17.86 /(\mathbf{6 9 . 1})$ & $>200$ & $>200$ & $>200$ & - & $>200$ & $7.020 /(49.3)$ & & \\
\hline Cytotoxicity & $>100$ & $56.59 /(\mathbf{2 1 9})$ & $36.0 /(\mathbf{1 2 0})$ & $8.21 /(\mathbf{3 0 . 1})$ & $95.56 /(373)$ & $*$ & $*$ & & & \\
\hline Antioxidant & $>100$ & $0.895(\mathbf{3 . 4 6})$ & $2.0 /(6.69)$ & $8.72 /(32.0)$ & $19.5 /(\mathbf{7 6 . 1})$ & $*$ & * & & $2.0 /(\mathbf{1 1 . 3})$ & \\
\hline $\begin{array}{l}\text { Mg Vit C equivalents/g dry } \\
\text { weight }\end{array}$ & - & 2234 & 1000 & 229.4 & 102.56 & & & & & \\
\hline Antibacterial & $500 /(\mathbf{1 5 9 0})$ & $250 /(\mathbf{9 6 8})$ & $125 /(\mathbf{4 1 8})$ & - & - & * & $*$ & & & $100 /(\mathbf{1 3 6})$ \\
\hline
\end{tabular}

$\left(^{*}\right)$ Not tested, (-) not active. The bold numbers represent the \% activity of each compound expressed in $\mu \mathrm{mol}$.

$\left\{[\alpha]_{\mathrm{D}}^{24}-4.7\left(\mathrm{c} 0.738, \mathrm{CHCl}_{3}\right)\right\}$, is almost identical to that reported (Ganci et al. 2000) for methyl (3S)-3-hydroxy-5-phenylpentanoate $\left\{[\alpha]_{\mathrm{D}}^{25}-3.35\left(\mathrm{c} 1, \mathrm{CHCl}_{3}\right)\right\}$.

The chemical data for (3S)-4-hydroxyphenetyl 3-hydroxy5-phenylpentanoate $=(3 S)$-3-hydroxy-5-phenylpentanoic acid 2(4-hydroxyphenyl)-ethyl ester (1) are the following: colorless needles ( $\mathrm{Me}_{2} \mathrm{CO}-n$-pentane), mp 92-93 ${ }^{\circ} \mathrm{C} ;[\alpha]_{\mathrm{D}}{ }^{24}-4.7$ (c $\left.0.738, \mathrm{CHCl}_{3}\right)$; IR (KBr) $v_{\max } 3446,3312,3060,3021,2925$, $1721,1614,1598,1519,1454,1399,1242,1213,1183,1172$, 1147, 1036, 800, 752, $700 \mathrm{~cm}^{-1} ;{ }^{1} \mathrm{H}$ NMR $\delta: 7.24(2 \mathrm{H}$, br t, $J_{\text {ortho }}=7.5 \mathrm{~Hz}, \mathrm{H}-8$ and H-10), $7.17\left(2 \mathrm{H}\right.$, br d, $J_{\text {ortho }}=7.6 \mathrm{~Hz}$, $\mathrm{H}-7$ and $\mathrm{H}-11), 7.14\left(1 \mathrm{H}, \mathrm{tt}, J_{\text {ortho }}=7.7 \mathrm{~Hz}, J_{\text {meta }}=1.2 \mathrm{~Hz}, \mathrm{H}-\right.$ 9), $7.02\left(2 \mathrm{H}, \mathrm{dt}, J_{\text {ortho }}=8.6 \mathrm{~Hz}, J_{\text {meta }}=2.4 \mathrm{~Hz}, \mathrm{H}-4^{\prime}\right.$ and $\mathrm{H}-$ $\left.8^{\prime}\right), 6.69\left(2 \mathrm{H}, \mathrm{dt}, J_{\text {ortho }}=8.6 \mathrm{~Hz}, J_{\text {meta }}=2.4 \mathrm{~Hz}, \mathrm{H}-5^{\prime}\right.$ and $\left.\mathrm{H}-7^{\prime}\right)$, $4.22\left(1 \mathrm{H}, \mathrm{dt}, J_{\mathrm{gem}}=10.8 \mathrm{~Hz}, J_{\mathrm{vic}}=6.9 \mathrm{~Hz}, \mathrm{H}_{\mathrm{A}}-1^{\prime}\right), 4.19(1 \mathrm{H}, \mathrm{dt}$, $\left.J_{\text {gem }}=10.8 \mathrm{~Hz}, J_{\text {vic }}=6.9 \mathrm{~Hz}, \mathrm{H}_{\mathrm{B}}-1^{\prime}\right), 3.96\left(1 \mathrm{H}, \mathrm{tt}, J_{3,2 \mathrm{~A}}=J_{3,4 \mathrm{~A}}=5.0 \mathrm{~Hz}\right.$, $\left.J_{3,2 \mathrm{~B}}=J_{3,4 \mathrm{~B}}=8.0 \mathrm{~Hz}, \mathrm{H}-3\right), 2.80\left(2 \mathrm{H}, \mathrm{t}, J_{\mathrm{vic}}=6.9 \mathrm{~Hz}, 2 \mathrm{H}-2^{\prime}\right), 2.74(1 \mathrm{H}$, ddd, $\left.J_{\text {gem }}=13.5 \mathrm{~Hz}, J_{5 \mathrm{~A}, 4 \mathrm{~A}}=9.2 \mathrm{~Hz}, J_{5 \mathrm{~A}, 4 \mathrm{~B}}=5.9 \mathrm{~Hz}, \mathrm{H}_{\mathrm{A}}-5\right), 2.62(1 \mathrm{H}$, ddd, $\left.J_{\text {gem }}=13.5 \mathrm{~Hz}, J_{5 \mathrm{~B}, 4 \mathrm{~A}}=7.0 \mathrm{~Hz}, J_{5 \mathrm{~B}, 4 \mathrm{~B}}=9.3 \mathrm{~Hz}, \mathrm{H}_{\mathrm{B}}-5\right), 2.47(1 \mathrm{H}$, dd, $\left.J_{\text {gem }}=15.0 \mathrm{~Hz}, J_{2 \mathrm{~A}, 3}=5.0 \mathrm{~Hz}, \mathrm{H}_{\mathrm{A}}-2\right), 2.41\left(1 \mathrm{H}, \mathrm{dd}, J_{\text {gem }}=15.0 \mathrm{~Hz}\right.$, $\left.J_{2 \mathrm{~B}, 3}=8.0 \mathrm{~Hz}, \mathrm{H}_{\mathrm{B}}-2\right), 1.74(2 \mathrm{H}, \mathrm{m}, 2 \mathrm{H}-4) ;{ }^{13} \mathrm{C} \mathrm{NMR} \delta: 173.4(\mathrm{C}, \mathrm{C}-1)$, 157.1 (C, C-6'), 143.3 (C, C-6), 130.9 (2CH, C-4' and C-8'), 130.0 (C, C-3'), 129.5 (2CH, C-7 and C-11), 129.4 (2CH, C-8 and C-10), 126.8 $(\mathrm{CH}, \mathrm{C}-9), 116.2\left(2 \mathrm{CH}, \mathrm{C}-5^{\prime}\right.$ and $\left.\mathrm{C}-7^{\prime}\right), 68.6(\mathrm{CH}, \mathrm{C}-3), 66.6\left(\mathrm{CH}_{2}, \mathrm{C}-1^{\prime}\right)$, $43.5\left(\mathrm{CH}_{2}, \mathrm{C}-2\right), 40.0\left(\mathrm{CH}_{2}, \mathrm{C}-4\right), 35.2\left(\mathrm{CH}_{2}, \mathrm{C}-2^{\prime}\right), 32.8\left(\mathrm{CH}_{2}, \mathrm{C}-5\right)$; negative-ion HRESIMS $m / z 313.1453[\mathrm{M}-\mathrm{H}]^{-}$(calcd for $\mathrm{C}_{19} \mathrm{H}_{21} \mathrm{O}_{4}$, 313.14403), $627.2985[2 \mathrm{M}-\mathrm{H}]^{-}$(calcd for $\mathrm{C}_{38} \mathrm{H}_{43} \mathrm{O}_{8}, 627.29589$ ); anal. C 72.63\%, $\mathrm{H} 7.01 \%$, calcd for $\mathrm{C}_{19} \mathrm{H}_{22} \mathrm{O}_{4}, \mathrm{C} 72.59 \%, \mathrm{H} 7.05 \%$.

\section{Identification of compounds $\mathbf{2}-\mathbf{7}$}

The previously known substances $2^{\prime}, 4^{\prime}, 6^{\prime}-$ trihydroxydihydrochalcone (2) (Crombie et al. 1988; Hufford and Lasswell 1978), 2',6',4-trihydroxy-4'-methoxydihydrochalcone (3) (Hermoso et al. 2003; Mabry et al. 1975), 2',6'-dihydroxy4'-methoxydihydrochalcone (4) (Hermoso et al. 2003; Nilsson 1961), 5,7-dihydroxyflavanone [(2S)-pinocembrin] (5) (Bick et al. 1972; Miyakado et al. 1976), 2',6'-dihydroxy-4',4-dimethoxy dihydrochalcone (6) (Nilsson 1961) and (2R,3R)-3,5,7-trihydroxy3-O-acetylflavanone (7) (Kumazawa et al. 2002; Tomás-Barberán et al. 1993), were identified by their physical (mp, $\left.[\alpha]_{\mathrm{D}}\right)$ and spectroscopic $\left({ }^{1} \mathrm{H}\right.$ and ${ }^{13} \mathrm{C}$ NMR and mass spectra) data, including NMR 2D-COSY, HSQC and HMBC experiments that allowed the unequivocal assignment of their structures.

\section{Tyrosinase inhibitory activity}

Ethanolic leaf extract of $G$. flanaganii was tested for tyrosinase activity using L-tyrosine as the substrate. It showed inhibition of the enzyme exhibiting 95\% inhibition at $200 \mu \mathrm{g} / \mathrm{ml}$. Isolation of active compounds was carried out using a bioassay-guided fractionation. Ethanolic leaf extract of $G$. flanaganii was subjected to a series of columns to which seven compounds were isolated (Fig. 1). Com- pound 2 exhibited the best inhibitory activity of the enzyme as compared to the other compounds with the $\mathrm{IC}_{50}$ value of $69.1 \mu \mathrm{M}$ Compounds 1, 3, 4, 5 and $\mathbf{7}$ exhibited 31, 11.3, 24, 22 and 35\% inhibition of tyrosinase enzyme at $200 \mu \mathrm{g} / \mathrm{ml}$. Compound $\mathbf{6}$ did not show any significant inhibition of the enzyme at the highest concentration tested $(200 \mu \mathrm{g} / \mathrm{ml})$.

\section{Cytotoxicity}

Fig. 2 shows the effect of G. flanaganii, isolated compounds and positive control (Kojic acid) on cell viability and melanin production by melanocytes cells. G. flanaganii showed significant inhibition $(P<0.05)(20 \%)$ of melanin production at $6.25 \mu \mathrm{g} / \mathrm{ml}$ while $80 \%$ of cells were found to be viable, thus indicating low levels of cytotoxicity $\left(\mathrm{IC}_{50}<400 \mu \mathrm{g} / \mathrm{ml}\right)$. Compound 5 showed less toxicity effect of the cells with the $\mathrm{IC}_{50}$ of $373 \mu \mathrm{M}$ and $10 \%$ reduction in melanin content of the cells at $1.5 \mu \mathrm{g} / \mathrm{ml}$. Compound 4 has shown toxicity effect of the cells giving low cell viability (less than $30 \%$ ) at most concentrations tested with the $\mathrm{IC}_{50}$ of $30.1 \mu \mathrm{M}$. Compound 3 was less toxic to the cells at lower concentrations with the $\mathrm{IC}_{50}$ of $120 \mu \mathrm{M}$ and compound 2 was also less toxic with the $\mathrm{IC}_{50}$ value of $219 \mu \mathrm{M}$. Compound 1 showed no toxicity effect of the cells even at the highest concentrations tested with no reduction of melanin content of the cells at all concentrations. These results were analyzed in comparison with the positive drug kojic acid.

\section{Antioxidant activity}

Greyia flanaganii ethanol extract and isolated compounds were further tested for their antioxidant activity. Due to low yield of 6 and 7 no further tests were done for these compounds. G. flanaganii extract exhibited above $90 \%$ radical scavenging activity at higher concentrations (Table 1). Vitamin C showed complete antioxidant activity shown by clear wells almost in all concentrations tested. All four compounds tested showed good inhibitory activity of the radical formation in almost all concentrations tested. The $\mathrm{EC}_{50}$ values of all the compounds are represented in Table 1.

\section{Antibacterial activity}

G. flanaganii ethanol extract and compound 1 showed inhibition of the growth of bacteria exhibiting the MIC value of $250 \mu \mathrm{g} / \mathrm{ml}$ and $1590 \mu \mathrm{M}$ respectively as compared to erythromycin with the MIC value of $136 \mu \mathrm{M}$. Compounds 2 and 3 also showed inhibition of the growth of the bacteria by exhibiting the MIC value of 968 and $418 \mu \mathrm{M}$ respectively as compared to that of the positive control. Compounds $\mathbf{4}$ and $\mathbf{5}$ did not show any inhibitory activity of the bacteria even at the highest concentrations tested $(500 \mu \mathrm{g} / \mathrm{ml})$ (Table 1).

The activity of plant extracts and their bioactive constituents have previously being explored for their tyrosinase inhibitory activity. Even in this study the plant extracts selected showed some inhibitory activity of the enzyme. Polyphenols have been identified 


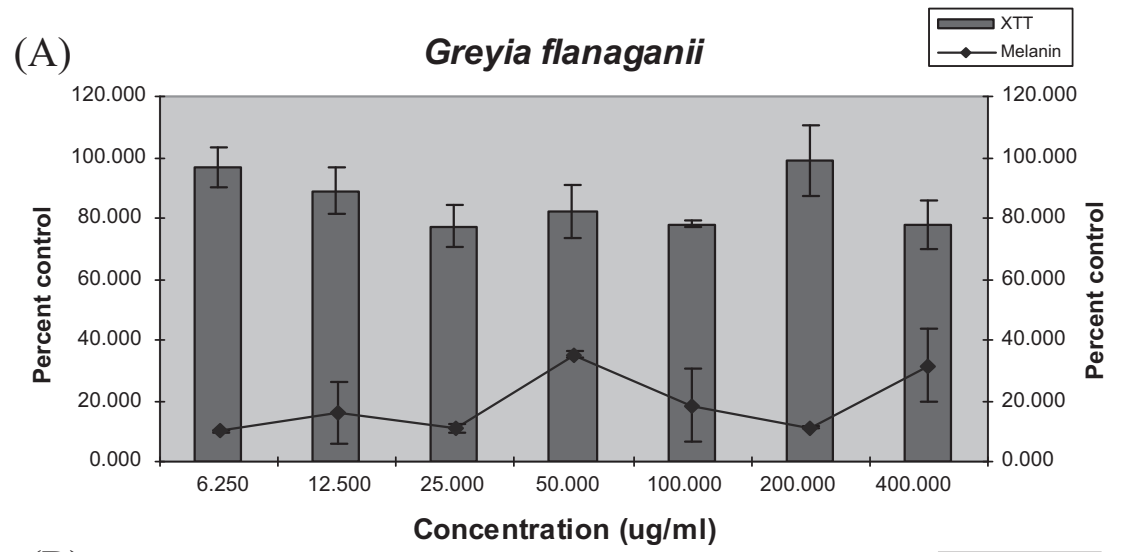

(B)
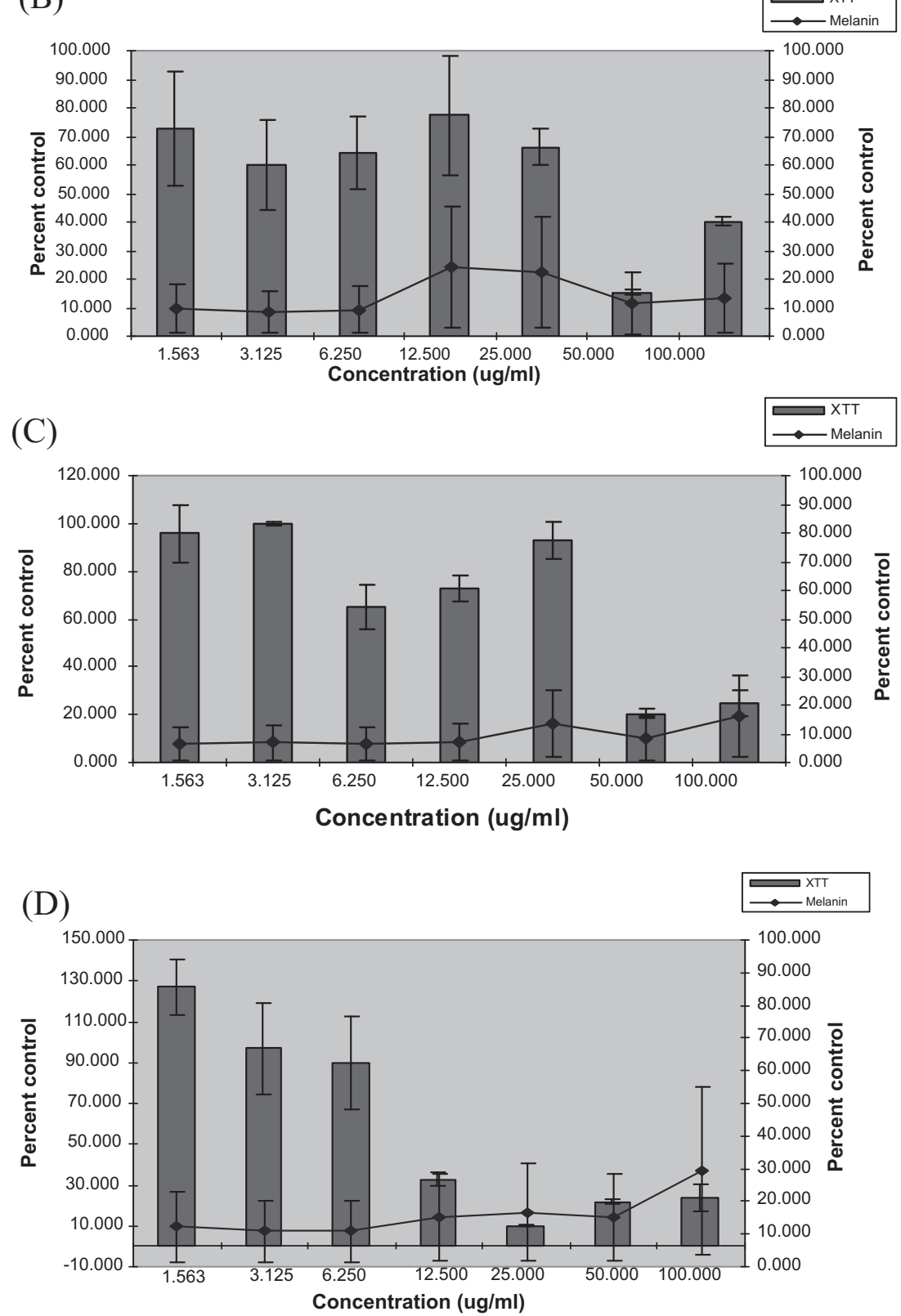

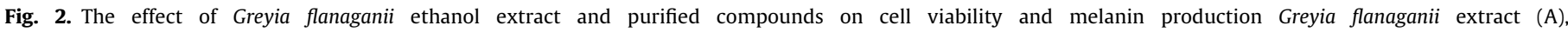

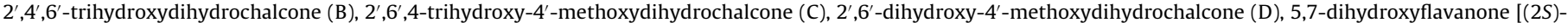
pinocembrin] (E), 4-hydroxyphenethyl 3-hydroxy-5-phenylpentanoate (F), Koji acid (positive control) (G). 
(E)

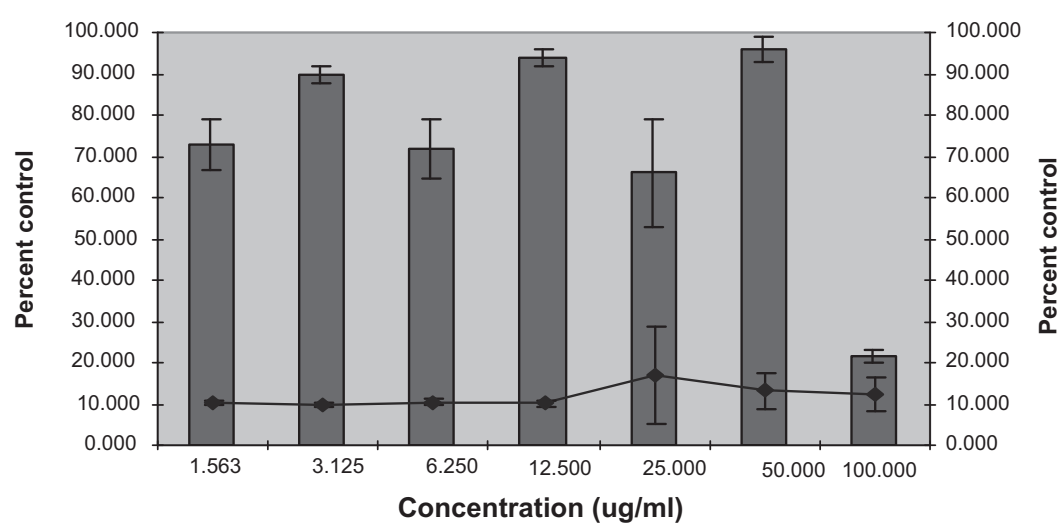

(F)

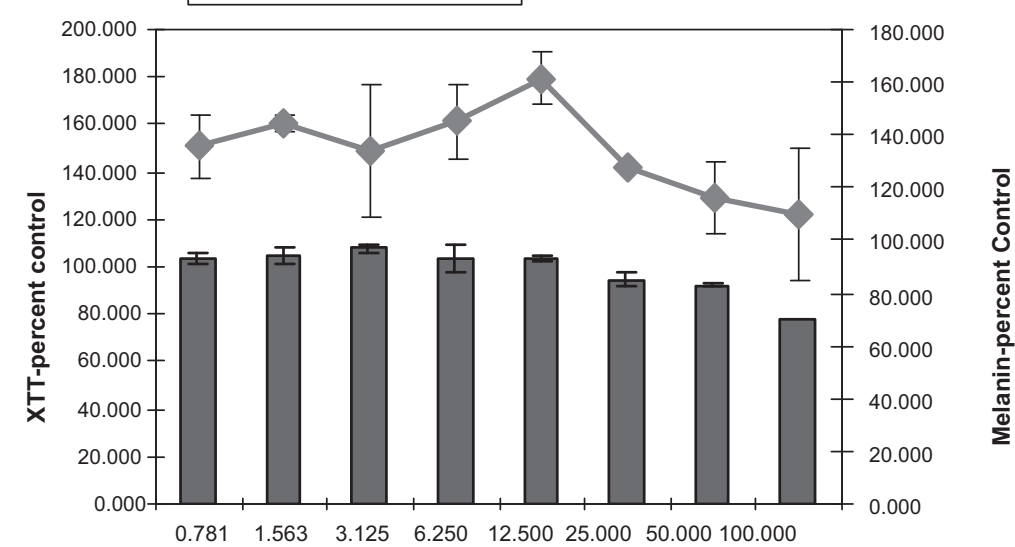

Concentration $(\mu \mathrm{g} / \mathrm{ml})$
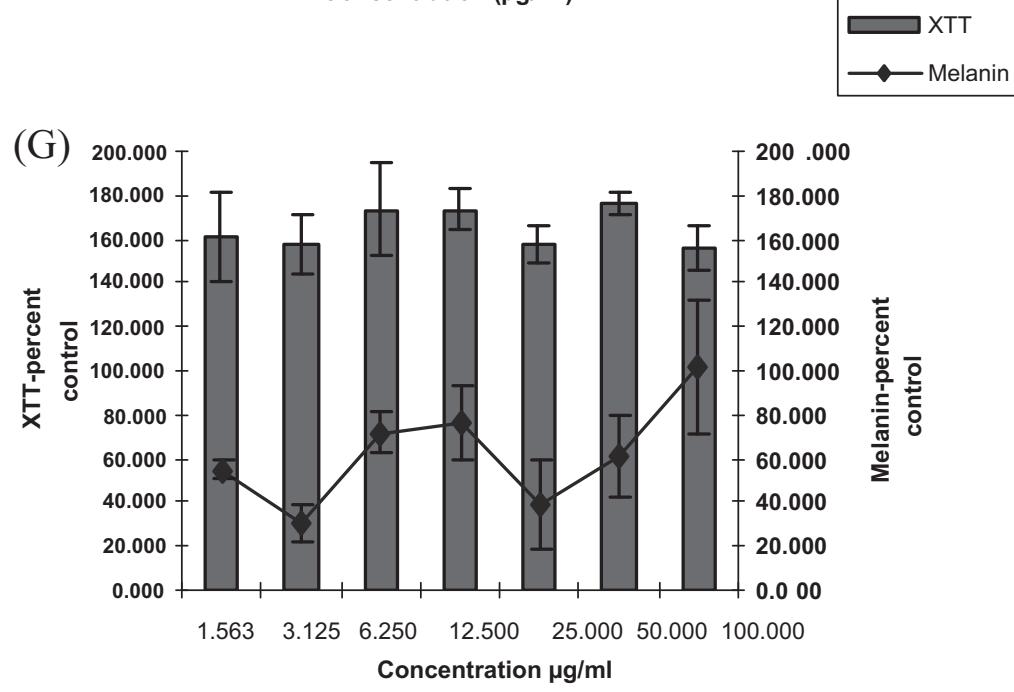

Fig. 2. (Continued) 
as a group of compounds containing multiple phenolic functionalities. They are produced as secondary metabolites by higher plants and have numerous biological activities (Kim and Uyama 2005). Flavonoids are one of the most numerous groups of plant polyphenols which are widely distributed in leaves, bark and flowers. Chalcones and flavonoids are a group of polyphenols compounds which have been studied in details previously. The antityrosinase activity results found in this study compare to the results found in a study by Tanaka et al. (1985) and Ichino et al. (1987) for this two groups of compounds isolated. Examples of Flavonols include Kaempferol, Luteolin, Epigallocatechin etc. (Kim and Uyama 2005). All compounds isolated showed strong radical scavenging activity as compared to vitamin C (Table 1 ). This results show that the compounds (flavones and chalcones) are most likely responsible for the antioxidant activity of $G$. flanaganii extract. As these compounds and the extract showed good tyrosinase inhibition activity, low toxicity, antioxidant and antibacterial activity this proves their capability to be used as skin lighteners, though the mode of action for each and in vivo studies are required to give conclusive results to be skin lighteners.

\section{Acknowledgements}

The authors thank NRF and Canon Collins trust for the financial support. This work was also supported by funds from the Spanish 'Ministerio de Ciencia e Innovación', Grant No. CTQ2009-10343, and from the 'Consejería de Educación de la Comunidad de Madrid' (Project CAPOTE-S209/PPQ-1752). This publication is part of the thesis submitted by the first author to the Department of Plant Science of University of Pretoria.

\section{References}

Anon, 1998. Environmental Guidelines to Practical Forest Management. Forest and Park Edita, Helesinki.

Bianco, A., Chiacchio, M.A., Grassi, G., Iannazzo, D., Piperno, A., Romeo, R., 2006. Phenolic components of Olea europea: isolation of new tyrosol and hydroxytyrosol derivatives. Food Chemistry 95, 562-565.

Bick, I.R.C., Brown, R.B., Hillis, W.E., 1972. Three flavanones from leaves of Eucalyptus sieberi. Australian Journal of Chemistry 25, 449-451.

Bohm, B.A., Chan, J., 1992. Flavonoids and affinities of Greyiaceae with a discussion of the occurrence of B-ring deoxyflavonoids in dicotyledonous families. Systematic Botany 17 (2), 272-281.

Calis, I., Kuruüzüm, A., Demirezer, L.Ö., Sticher, O., Ganci, W., Rüedi, P., 1999. Phenylvaleric acid and flavonoid glycosides from Polygonum salicifolium. Journal of Natural Products 62, 1101-1105.

Crombie, L., Crombie, W.M.L., Firth, D.F., 1988. Terpenylations using $(R)-(-)-\alpha-$ phellandrene. Synthesis of the $(3 S, 4 R)-8,9$-dihydro-o-and -p-cannabidiols, their iso-THC's, and the natural dihydochalcone ((3S,4R)-(+)-linderatin. Journal of the Chemical Society, Perkin Transactions 1, 1251-1253.

Curto, E.V., Kwong, C., Hermersdorfer, H., Glatt, H., Santi, C., Virador, V., Hearing, V.J., Dooley, T.P., 1999. Inhibors of mammalian melanocytes tyrosinase: in vitro comparison of alkyl esters of gentisic acid with other putative inhibitors. Biochemical Pharmacology 57, 665-672.
Ganci, W., Kuruüzüm, A., Calis, I., Rüedi, P., 2000. Determination of the absolute configuration of (-)-(3R)-O- $\beta$-D-glucopyranosyloxy-5-phenylpentanoic acid from Polygonum salicifolium. Chirality 12, 139-142.

Halder, R.M., Richards, M.D., Richards, G.M., 2004. Topical agents used in the management of hyperpigmentation. Skin Therapy Letter 9, 453.

Hermoso, A., Jiménez, I.A., Mamani, Z.A., Bazzocchi, I.L., Piñero, J.E., Ravelo, A.G., Valladares, B., 2003. Antileishmanial activities of dihydrochalcones from Piper elongatum and synthetic related compounds, structural requirements for activity. Bioorganic and Medicinal Chemistry 11, 3975-3980.

Hufford, C.D., Lasswell Jr., W.L., 1978. Antimicrobial activities of constituents of Uvaria chamae. Lloydia 41, 156-160.

Ichino, K., Tanaka, H., Ito, K., 1987. Two novel flavonoids from the leaves of Lindera umbellata var, Lancea and L. umbellata. Phytochemistry 3, 955-956.

Kim, Y.-M., Uyama, H., 2005. Tyrosinase inhibitor from natural and synthetic sources: structure, inhibition mechanism and perspective for the future. Cellular and Molecular Life Science CMLS 62, 1707-1723.

Kumazawa, S, Hayashi, K., Kajiya, K., Ishii, T., Hamasaka, T., Nakayama, T., 2002. Studies of the constituents of Uruguayan propolis. Journal of Agricultural and Food Chemistry 50, 4777-4782.

Lee, K.T., Kim, B.J., Kim, J.H., 1997. Biological screening of 100 plant extracts for cosmetic use (I): inhibition activities of tyrosinase and DOPA auto-oxidation. International Journal of Cosmetic Science 19, 275-284.

Lim, Y.-H., Kim, I.-H., Seo, J.-J., 2007. In vitro activity of Kaempferol isolated from the Impatiens balsamina alone and in combination with erythromycin or clindamycin against Propionibacterium acnes. Journal of Microbiology 5, 473-477.

Mabry, T.J., Sakakibara, M., King, B., 1975. Asebotin and its aglucone from three species of Rhododendron. Phytochemistry 14, 1448-1450.

Mbambezeli, G., 2005. Cryptocarya wodii Engl. Krstenboch National Botanical Garden http://www.plantzafrica.com/plantcd/crytocarwood.htm.

McGaw, L.J., Eloff, J.N., 2005. Screening of 16 poisonous plants for antibacterial, anthelmintic and cytotoxic activity in-vitro. South African Journal of Botany 71, 302-306.

Miyakado, M., Kato, T., Ohno, N., Mabry, T.J., 1976. Pinocembrin and (+)- $\beta$-eudesmol from Hymenoclea monogyra and Baccharis glutinosa. Phytochemistry 15, 846.

Momtaz, S., Mapunya, B.M., Houghton, P.J., Edgerly, C., Hussein, A., Naidoo, S., Lall, N. 2008. Tyrosinase inhibition by extracts and constituents of Sideroxylon inerme L. stem bark, used in South Africa for skin lightening. Journal of Ethnopharmacology 119, 507-512.

Nerya, O, Vaya, J., Musa, R., Izrael, S., Ben-Arie, R., Tamir, S., 2003. Glabrene and isoliquiritigen as tyrosinase inhibitors from licorice roots. Journal of Agricultural Food Chemistry 51, 1201-1207.

Nilsson, M., 1961. Dihydrochalcones from the fronds of Pityrogramma chrysophylla var. marginata Domin. Acta Chemica Scandinavica 15, 154-158.

Sahin, F., Karaman, I., Gulluce, M., Ogutcu, H., Sengul, M., Adiguzel, A., Ozturk, S., Kotan, R., 2003. Evaluation of antimicrobial activities of Satureja hortensis L. Journal of Ethnopharmacology 87, 61-65.

Tanaka, T., Ichino, K., Ito, K., 1985. A novel flavanone, linderatone, from Lindera umbellata. Chemical and Pharmaceutical Bulletin 33 (6), 2602-2604.

Toit, R., Volsteedt, Y., Apostolides, Z., 2001. Comparison of the antioxidant content of fruits, vegetables and teas measured as vitamin C equivalents. Toxicology 166 , 63-69.

Tomás-Barberán, F.A., García-Viguera, C., Vit-Oliver, P., Ferreres, F., Tomás-Lorente, F., 1993. Phytochemical evidence for the botanical origin of tropical propolis from Venezuela. Phytochemistry 34, 191-196.

Wang, K.-H., Lin, R.-D., Hsu, F.-L., Huang, Y.-H., Chan, H.-C., Lee, M.-H., 2006. Cosmetic applications of selected traditional Chinese herbal medicines. Journal of Ethnopharmacology 106, 353-359.

Wu, L.-C., Chen, Y.-C., Ho, J.-A., Yang, C.-S., 2003. Inhibitory effect of Red kojic extracts on mushroom tyrosinase. Journal of Agriculture and Food Chemistry $51,4240-4246$

Yesilada, E., 2005. Past and the future contributions to traditional medicine in the health care system of the Middle-East. Journal of Ethnopharmacology 100, 135-137. 